Economics Development Analysis Journal 6 (4) (2017)

\title{
The Analysis of Monetary Transmission Mechaniscm by Expectation Patterns in Influencing the Inflation
}

\author{
Ilma Ulfatul ${ }^{\bowtie}$
}

Economics Development Department, Economics Faculty, Universitas Negeri Semarang

\section{Article Info \\ Article History: \\ Received Juny2017 \\ Accepted Agust 2017 \\ Published November \\ 2017}

\section{Keywords:}

Transmission, Monetary

Policy, expectation,

inflation, Indonesia

\begin{abstract}
Bank Indonesia set inflation targeting framework from 1 July 2005 by publicizing the inflation target or forward inflation to the public. However, the phenomenon show that most of the actual inflation of Indonesia is not in accordance with inflation targeting that have been set by Bank Indonesia. The purpose of this research is to analyze and know the flow of monetary policy transmission mechanism of expectation line in influencing inflation, to analyze and to know the influence of long-term and short-term and the shocks of interest rate, exchange rate, inflation expectations, output gap and GDP on inflation in Indonesia. The variables used in this research are BI Rate, Exchange Rate, Inflation Expectation, Output Gap, GDP and Inflation. The data used in this research is monthly data of time series from January 2006 until June 2016 which come from Bank Indonesia (BI) and Central Statistic Agency (BPS). The method used in this research is Vector Error Correction Model (VECM). The result of research indicates that: The flow of monetary policy transmission mechanism of expectation line in influencing inflation in Indonesia runs continuously with indicated the existence of two-way relationship between exchange rate and inflation variable, in the short term, the BI Rate, Exchange Rate and Output Gap are significant and positively affect inflation, inflation expectation variables are significant and affect inflation and GDP variable is insignificant to inflation in Indonesia, while in long run variable affecting inflation rate are BI Rate and inflation expectations, based on the variance decomposits result shows that the biggest variant contributing to inflation in Indonesia is the BI Rate.
\end{abstract}




\section{INTRODUCTION}

Bank Indonesia sets the interest rate as one of the monetary policy instruments to influence the exchange rate which will ultimately affect the price level (Kadir, Priyo and Guruh 2008). The mechanism of monetary policy stipulated by the central bank to influence inflation is called the monetary policy transmission mechanism (Ascarya, 2002).

In Indonesia there are several types of monetary policy transmission mechanism mechanisms such as interest rate, exchange rate, asset price line, credit line and expectation line (Warjiyo, 2004). One important path in the monetary policy transmission mechanism is to achieve the ultimate goal is the mechanism of transmission of monetary policy path of expectations. This is due to the factors of uncertainty and trends in both the monetary sector as well as in the real sector. Inflation expectation path will be more effective with more credible monetary policy (Natsir, 2009). An expansionary monetary policy decreases the real interest rate and leads to a reduction in the real interest rate which boosts the investment and increase consequently the product (Mgadmi, 2015).

The monetary policy transmission mechanism of the expectation path is focused on the monetary policy set by the central bank directed at the formation of expectations concerning inflation and economic activity (Warjiyo and Solikin, 2003). Inflation expectations are formed through public announcements related to the inflation target to be achieved by the central bank in the future (Anwar and Chawwa, 2008). The target of monetary policy is generally set as to create an environment of manageable employment and affordable long-term interest rates (Turguttopba, 2017). Monetary policy which is one of the macroeconomic tools (the other being fiscal policy) has been used in stimulating economies towards the achievement of macroeconomic goals which include price stability, exchange rate stability, maintenance of equilibrium balance of payment, employment generation, promotion of output and sustainable growth (Uzoma, 2017).

Bank Indonesia stipulates the inflation targeting framework (ITF) from 1 July 2005 as a form of increased credibility of Bank Indonesia in order to maintain stability of inflation rate in Indonesia (Kadir, Priyo \& Guruh 2008). Bank

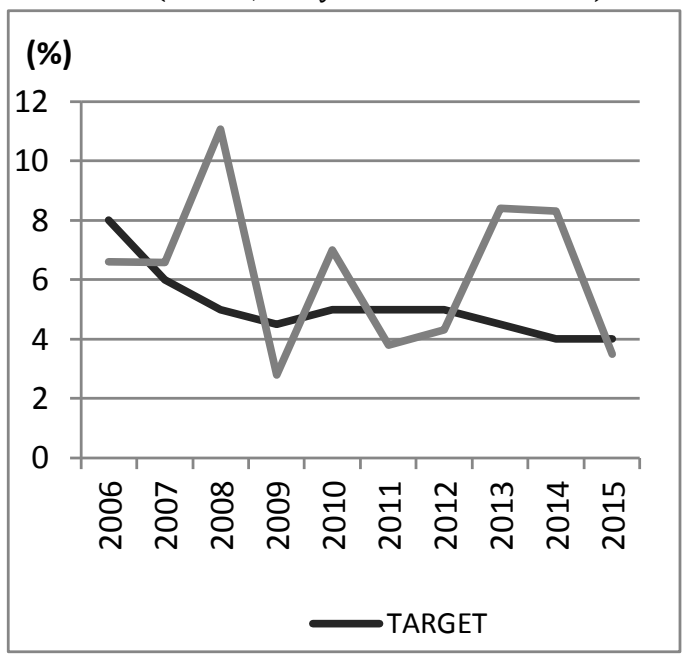

Indonesia sets inflation target or inflation target which is the reference for the perpetrators of society and society in carrying out their economic activities (Yodiatmaja, 2012).

Inflation is an indicator in maintaining the stability of economic resource allocation in a country. The high and unstable inflation conditions will cause various negative impacts. Therefore, each country seeks to maintain stable inflation rates at a low and stable level (Suseno and Siti, 2009). In general, inflation is caused by an increase in demand for goods and services is quite significant. According to Philips Curve theory, inflation is caused by (a) demand pull inflation, (b) supply inflation / supply shock / supply shock inflation, and (c) inflation expectations.

Figure 1. Inflation Target and Realization Sumber: Bank Indonesia

The development of inflation in Indonesia from 2006-2015 shows a fluctuating condition. In 2006, inflation in Indonesia reached 6.6\%. In 2015 the rate of inflation shows a percentage of $3.5 \%$. This shows that inflation over the past 10 years has decreased compared to inflation in 2006. 
However, the inflation rate in the previous year of 2013 and 2014 shows higher percentage of $8.4 \%$ and $8.3 \%$. Inflationary conditions in Indonesia from 2006-2015 indicate a discrepancy between the actual inflation rate in Indonesia and the inflation target set by Bank Indonesia, even from 2006-2015 there are only 3 years of actual inflation rate in accordance with the inflation target set by Bank Indonesia in 2007, 2012 and 2015.

Natsir (2009) who analyzed the monetary policy transmission mechanism of the 1990 line: 2-2007: 1 suggests that the ultimate goal of monetary policy in Indonesia takes 12 quarters, the response of the variables on the expectation path is relatively unfavorable to the pressure of monetary policy instruments.

Kurniasari (2016) examines the mechanism of monetary policy transmission between the interest rate channel and the expected path. Research shows that in the short term in the path of variable expectations that can give effect to the inflation rate, among others, such as inflation expectations and exchange rates. While in the long term, the variable of BI Rate and Exchange Rate rate gives its influence to the inflation rate. For the mechanism of monetary policy transmission of the interest rate path in the short term and in the long term the variable who affected is PUAB (money market inter-bank) variable.

While, in another study Nurliana, Rizki and Redianto (2014) argue that to increase the effectiveness of the path of expectations, which as a result of inflation targeting and macroeconomic variables by improving communication between monetary authorities and economic agents that will affect in reducing disperse from expectations.

\section{RESEARCH METHOD}

This research uses Vector Error Correction Model (VECM) analysis model. VECM is a form of VAR that these restricted VAR was first introduced by Sims in 1980 as alaternatif models developed from models Auto Distributed Lag (ADL) with the consideration of minimizing the theoretical approach with the purpose of being able to explain economic phenomena as well (Widarjono, 2009), in VECM analysis consists of 8 stages, namely, Stationarity Test, Test Optimization Lag, Cointegration Test, Stability Test, Granger Causality Test, VECM, Impulse Response Function (IRF) and Variance Decomposite (VD).

The equations to be used in this research are:

$$
\begin{aligned}
\mathrm{INF}= & \beta_{0}+\beta_{1} \mathrm{BIRate}+\beta 2 \ln E \mathrm{R}+\beta_{3} \mathrm{EI} \\
& +\beta 4 \operatorname{lnOG}+\beta 5 \ln \mathrm{PDB}+\beta_{6} \mathrm{INF}+\varepsilon_{1 \mathrm{lt} .}(1)
\end{aligned}
$$

BI Rate $=\beta_{0}+\beta_{1}$ BIRate $+\beta 2 \ln E R+\beta_{3} E I$

$$
+\beta 4 \operatorname{lnOG}+\beta 5 \ln \mathrm{DDB}+\beta_{6} \mathrm{INF}+\varepsilon_{2 \mathrm{t} . .}
$$

$\operatorname{lnER}=\beta_{0}+\beta_{1}$ BIRate $+\beta 2 \ln E R+\beta_{3} \mathrm{EI}$ $+\beta 4 \operatorname{lnOG}+\beta 5 \ln \mathrm{PDB}+\beta_{6} \mathrm{INF}+\varepsilon_{3 t . .}(3)$

EI $\quad=\beta_{0}+\beta_{1}$ BIRate $+\beta 2 \ln E R+\beta_{3}$ EI $+\beta 4 \operatorname{lnOG}+\beta 5 \ln \mathrm{PDB}+\beta_{6} \mathrm{INF}+\varepsilon_{4 t} \ldots$ (3)

$\operatorname{lnOG}=\beta_{0}+\beta_{1}$ BIRate $+\beta 2 \ln E R+\beta_{3}$ EI $+\beta 4 \operatorname{lnOG}+\beta 5 \ln \mathrm{PDB}+\beta_{6} \mathrm{INF}+\varepsilon_{5} \ldots$ (4)

$\ln \mathrm{PDB}=\beta_{0}+\beta_{1}$ BIRate $+\beta 2 \ln E R+\beta_{3} \mathrm{EI}$ $+\beta 4 \operatorname{lnOG}+\beta 5 \ln \mathrm{PDB}+\beta_{6} \mathrm{INF}+\varepsilon_{6 t} .(5)$

Whereas:

BI $\quad$ : BI rate

LnER : Log natural of exchange rate

LnOG : Log natural Output Gap

LnPDB : Log natural GDP

INF : Inflation

$\beta_{1}-\beta_{10}$ :

$\beta_{0}$ : constant

$\varepsilon$ : error term

\section{RESULTS AND DISCUSSION}

The result of granger causality estimation shows the relationship between variables. The results of causality test show that there is a twoway relationship between exchange rate variables and inflation. This can be interpreted that the correlation between the exchange rate of rupiah and inflation. In other words, if there is a change in the exchange rate in this case, the exchange rate depreciated or the strengthening of the US dollar will result in higher import prices.

The high cost of imported inputs causes companies to increase marginal costs and cause the prices of domestically produced goods to 
become more expensive. On the other hand, output demand is assumed to be constant when the price of manufactured goods becomes more expensive, thereby promoting inflation and vice versa.

The results of the research on the flow of monetary policy transmission mechanism of the expected path show that the monetary policy transmission mechanism starting from the BI rate changes will give changes to inflation and exchange rate expectations. Therefore, exchange rate changes will be responded by inflation expectations, in this case changes in inflation expectations by the community also determine the amount of Output Gap due to changes in demand for outputs thus allowing the output gap. Output Gap changes that show positive or negative values indicate the occurrence of excessive demand or supply conditions resulting in an impact on inflationary changes.

In line with research conducted by Natsir (2009) on monetary policy transmission mechanism, the path of inflation expectation started from monetary policy changes through the influence of monetary policy instrument announced by Bank Indonesia. The implementation of expansionary monetary policy by lowering interest rates has an impact on inflation expectations. Meanwhile, the decline in interest rates also gives effect to the exchange rate with the lower interest rates the more demand for money to speculate. Inflation expectations by households will increase frequently with the depreciation of the rupiah.

Table 1. The Influence of Short and Long Term

\begin{tabular}{lll}
\hline Short term & & \\
Variables & coefficient & t-value \\
\hline BI rate & 2.798 & 2.529 \\
Exchange rate & 9.319 & 2.184 \\
Inflation expectation & 0.011 & 4.324 \\
Output Gap & 0.964 & 4.271 \\
GDP & 13.602 & 0.638 \\
Long ter, & & \\
Variable & Coefficient & $\mathrm{t}$-value \\
BI rate & 1.508 & 7.168 \\
Exchange rate & 3.824 & 1.788 \\
Inflation expectation & 0.013 & 3.421
\end{tabular}

\begin{tabular}{lll}
\hline Output Gap & 0.932 & 1.384 \\
GDP & 0.223 & 0.091 \\
\hline
\end{tabular}

Short Term Influence, the VECM test results based on Table 1. show that in the short term, the BI rate variable has significant and positive effect to influence inflation with the level of lag in the first lag. This can be interpreted if there is an increase in interest rate or BI rate of 1 percent then inflation will increase by 2.789 percent.

Due to an increase in BI rate will affect the increase in bank lending rates. Increased lending rates will be responded by reduced real sector investment that impacts on the decline in output with constant demand assumption, a decrease in output leads to an increase in the rate of inflation.

In addition to the BI Rate in the short run, the variables of inflation expectations are significantly and negatively able to influence inflation with the level of lag in the first lag. This can be interpreted that if there is an increase of 1 percent in inflation expectations, then inflation will decrease by 0.011 percent.

The decrease in inflation occurs when economic actors are adaptive to future inflation, in which case the companies and households estimates the inflation in the future increased, causing the expected interest rate to be lower and make people's motives to consume into higher than the public motives for saving.

The explanation of inflation expectations by economic actors capable of influencing a country's inflationary conditions is described in modern quantity theory by Irving Fisher. The theory of modern quantity or the theory of rational expectations explains the cause of inflation due to the psychology of the general public regarding the rise in prices in the future. The general public expects future inflation in the future due to the availability of relevant information (Sutawijaya and Zulfahmi, 2012).

VECM test results show that in the short term Output Gap variables are significantly and positively able to influence inflation with the level of lag in the first lag. It is significant if the value of t-statistical Output Gap variable is greater than t-table value. It can be explained that 
if the Output Gap shows a positive value it will cause inflation increased by 0.96 percent. A positive Gap output generally signifies that the actual output value is higher in comparison with its potential output. When a positive Output Gap is marked by an excess demand.

The relationship between Output Gap and inflation in a country is described in the Triangle Model. Triangel Model is a modern version of the Phillips curve model which assumes that there is a direct relationship between Output Gap and inflation. Output Gap changes not only affect inflation directly, but also through labor costs (Bolt \& Van, 1999).

The inflation relationship with Output Gap is evidenced by research conducted by Patra and Partha (2010) resulting that inflation and Output Gap have a positive relationship. Lag future inflation indicates a high relationship with Output Gap. Therefore, the inflation lag is measured by the Output Gap series and the Output Gap measurement causes inflation, this is consistent with the Phillips curve theory.

In addition to the variable BI Rate, Ouput Gap and expectations, exchange rate variables are also able to influence inflation. The VECM test results show that in the short term the exchange rate variable is significantly and positively able to influence inflation with the level of lag in the third lag.

The depreciation of the rupiah exchange rate or the strengthening of the US dollar will result in higher import prices. The high cost of imported inputs causes companies to increase marginal costs and cause the prices of domestically produced goods to become more expensive. On the other hand, output demand is assumed to be constant when the price of manufactured goods becomes more expensive, thus encouraging inflation.

VECM test results show that in the short term GDP variables have positive and insignificant effect on inflation in Indonesia. It is said to be insignificant because the t-statistic value of the GDP variable is smaller than the ttable value. The t-statistical value of GDP variables showed as $0.638<1.984$ with coefficient of $13.602 \%$. The results of this study are similar to those of Endri (2008) and wahyudi (2014) that in the short and long term the GDP variable has a positive and insignificant effect on the inflation rate in Indonesia.

Long Term Influence, VECM test results show that in the long run $\mathrm{BI}$ rate significantly and negatively affect inflation. This can be interpreted that if there is an increase in interest rate or BI rate of 1 percent then inflation will decrease by 1.50 percent. An increase in the BI rate will have an impact on the increase in savings interest rates. Increased interest rates savings responded by the community by storing funds in banks than spent on consumption. This makes the money supply held by the community will decrease so it will have an impact on the decline in the rate of inflation.

In line with research Kurniasari (2015), Silasa (2016) and Ferry (2006) that in the long run the $\mathrm{BI}$ rate significantly and negatively affect the rate of inflation. In addition, Keynes's interest rate theory is that interest rates are one of the monetary phenomena in which interest rates are determined by demand and supply of money (Kuncoro, 2001). Keynes noted that to cope with the high inflation rate the central bank will raise high interest rates. This is so that the amount of public savings will increase so that the money supply circulating in the community has decreased and the rate of inflation can be muffled.

The result of VECM test shows that in the long run, the variable of inflation expectation has significant effect and negative to inflation. The coefficient value of inflation expectation variable based on VECM test result is 0,0013 percent. This can be interpreted that if there is a change in inflation expectations by the public at 1 percent it will affect the change in inflation in which inflation decreased by 0.0013 percent.

The decrease in inflation occurs when economic actors are adaptive to future inflation, in which case the companies and households estimates increasing inflation in the future, causing the expected interest rate to be lower and make people's motives to consume into higher than the public motives for saving. Therefore, it encourages the central bank to raise the nominal 
reference rate. The increase in nominal interest rates encourages people to prefer to save money rather than to consume. So the amount of money circulating in the community to be reduced and able to reduce the rate of inflation.

The explanation of inflation expectations by economic actors capable of influencing a country's inflationary conditions is described in modern quantity theory by Irving Fisher. The theory of modern quantity or the theory of rational expectations explains the cause of inflation due to the psychology of the general public regarding the rise in prices in the future. The general public expects future inflation in the future due to the availability of relevant information (Sutawijaya and Zulfahmi, 2012).

The VECM test results show that in the long run the exchange rate variable has no significant and positive effect on inflation. It is said to be insignificant if the t-statistic value of the exchange rate variable is less than the $t$-table value. The value of t-statistics of exchange rate variables shows as $1.788<1.984$ and has a coefficient of 3.824 percent.

Similar results are also in line with research conducted by Silasa (2016) regarding long-term and short-term analysis of macroeconomic variables in an effort to stabilize inflation in Indonesia which indicates that longterm exchange rate variables have no significant effect on inflation in Indonesia.

VECM test results show that in long term Output Gap variable does not have a significant and positive effect on inflation. It is said to be insignificant because the t-statistical value of the Output Gap variable is smaller than the t-table value with the t-statistic value of $1.384<1.984$. Output Gap variable coefficient value based on VECM test results of 0.932 percent.

The results of this study are in line with the results of Nawatmi (2012) study related to Indonesia's inflation in view of phillips curve. Based on the results of VECM analysis that in the long run the output gap does not affect the growth of the inflation rate.

VECM test results show that in the long term GDP do not have a significant and positive effect on inflation. It is said to be insignificant because the t-statistic value of the GDP variable is smaller than the t-table value with the t-statistic value of $0.0091<1.984$. The coefficient value of GDP variables based on VECM test result is 0,223 percent.

The results of this study are in line with the results of Endri (2008) research related to the fator factors that determine the rate of inflation in Indonesia. Based on the results of analysis that in the long run the GDP has no effect on growth.

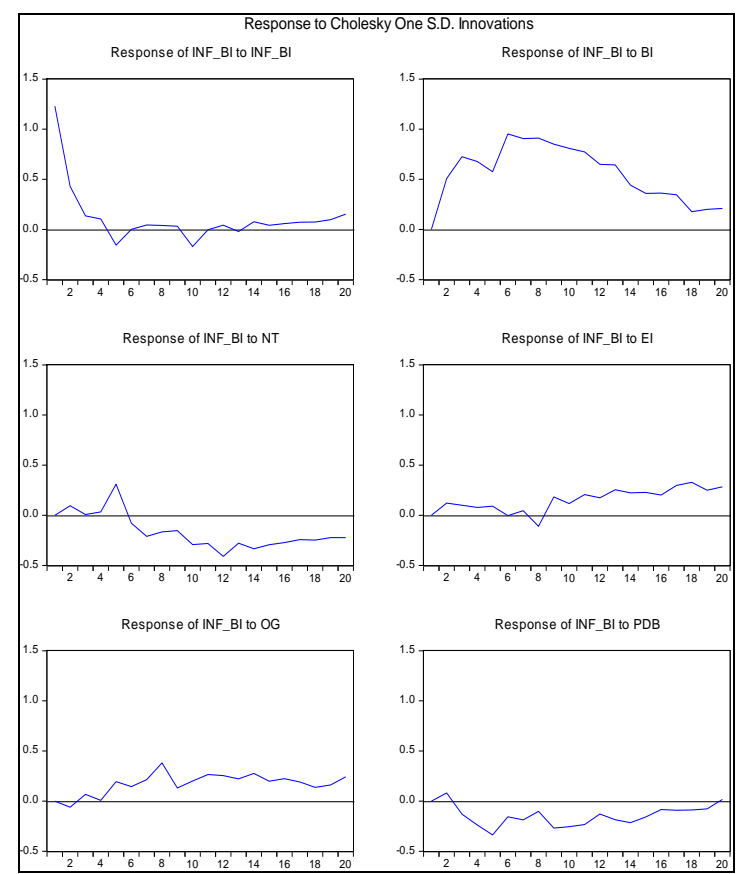

Figures 2. Impulse Responses Function

The Impulse Response Function Impact (IRF) test in Figure 3 shows the impact on inflation itself, $\mathrm{BI}$ rate, exchange rate, inflation expectations, Output Gap and GDP on inflation response. In the first month only shocks caused by inflation itself can be responded by inflation. While shocks caused by other variables are only responded by inflation in the second month. This is in the transmission process.

Inflation response due to shocks from BI rate, inflation expectations, exchange rate, gap 
output and GDP shows convergent conditions in the 20th month, this happens inflation has adjusted the impact of shocks from BI rate, inflation expectations, exchange rate, gap output and GDP or there are more dominant variables in impacting inflation.

Variance Decomposit also called as forcast error variance decomposition is a device in VECM model that is separate variation of the number of variables that are estimated to be shock components (Ajija et al, 2011).

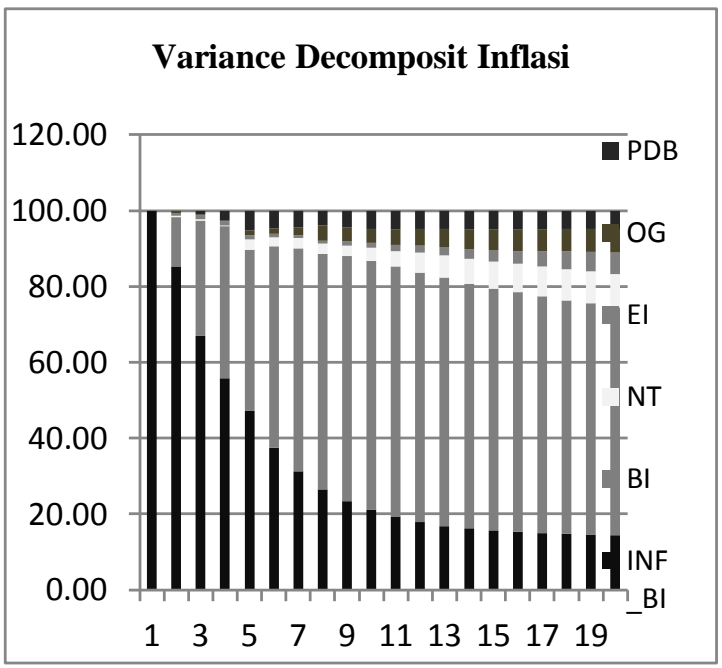

Figure 3. Inflation Variance Decomposit

The effect of the inflation shock itself on forecasting next month has decreased in influencing inflation fluctuations. Beginning in the 5 th month inflation fluctuations can be explained by the inflation variant itself of 47.21 percent, variant of BI rate of 42.39 percent, exchange rate variant of 2.87 percent, inflation expectation variant of 1.05 percent, Output variant Gap of 1.24 percent and GDP variant of 5.21 percent. In the 10th month period, the inflation variant shock itself has decreased in affecting inflation fluctuation of 21.25 percent, BI rate variant accounted for 65.53 percent in influencing inflation fluctuations. While the exchange rate variables accounted for inflation fluctuations of 3.48 percent, Output Gap of 3.75 percent, inflation expectations of 1.20 percent and GDP of 4.77 percent.

Until the 20th or final period of forecasting inflation fluctuations, BI variant variants become the most dominant variant affect inflation fluctuation, with the contribution of variant BI rate to inflation fluctuation of 60.02 percent, while the inflation variant itself can affect inflation fluctuations of 14, 49 percent. Meanwhile, the variant of inflation expectations until the end of the period is not able to explain significantly in influencing inflation fluctuations, this is because the variant of inflation expectations until the end of the period is only about 5, 67 percent lower than the BI rate variant of 60.02 percent and the exchange rate variant of 5.67 percent. Output Gap variants and GDP variants until the end of the period are able to explain the inflation variant of 6.32 percent and 4.77 percent respectively.

Based on the results of the decomposit variance it can be explained that the inflation variant is predominantly explained by the shock caused by the $\mathrm{BI}$ rate variant up to the end of the period of 60.02 percent. This indicates that the monetary policy transmission mechanism is capable of having a major impact on inflation fluctuations in accordance with the objective of monetary policy that is to maintain the stability of the inflation rate.

\section{CONCLUSION}

Changes in exchange rates are responded by inflation expectations, which changes in inflation expectations by communities impact on changes in output demand. The change in output demand by the community determines the value of the output gap, both positive and negative, which has an impact on inflationary changes.

Short-term effect indicates that in the process of working monetary policy transmission required time lag to be able to influence the ultimate goal of inflation. In the Short Run shows that the variable of BI Rate, inflation expectation and output gap able to influence inflation in Indonesia at first time lag, while exchange rate variable able to influence inflation in third time lag. Meanwhile, in the long run, the variable that can influence inflation is only the BI rate variable and inflation expectation. For exchange rate 
variables, output gaps and GDP show no significant effect on inflation in Indonesia.

In the first month only shocks caused by inflation itself can be responded by inflation. While the shock caused by other variables new response by inflation in the second month. The inflation response due to shocks from the BI Rate, exchange rate, inflation expectations, output gaps, and GDP shows the convergent conditions starting in the 20th month.

The inflation variant is predominantly explained by shocks caused by the BI rate variant until at the end of the period of 60.02 percent. While the variant of inflation itself in explaining the variant of inflation of 14.49 percent. Meanwhile, the variant of inflation expectation, Output Gap variant and GDP variant until the end of the period able to explain the variant of inflation respectively at 5.67 percent, 6.32 percent, and 4.77 percent. This indicates that the monetary policy transmission mechanism is capable of having a major impact on inflation fluctuations in accordance with the objective of monetary policy that is to maintain the stability of the inflation rate.

\section{REFERENCES}

Ajija, R. Scochrul. Et al. (2011). Smart Way to Master E-Views. Salemba Empat. Jakrta

Anwar, Muslimin \& Chawwa, Tevi. (2008). Analysis of Inflation Expectations Indonesia Post ITF. Center for Education and Central Bank Studies. Bank Indonesia.

Ascarya. (2002). Monetary Control Instruments. Central Bank Book Series No. 3. Center for Education and Central Bank Studies (PPSK). Bank Indonesia.

Central Statistics Bureau. Watermark Exchange Rates. Various Editions.

Bank Indonesia. Consumer Surveys. Various Editions . Indonesian Economic Report. Various Editions

Indonesian Economic and Financial Statistics. Various Editions

Basith, Ahmad. (2007). Analysis of Transmission Mechanism of Monetary Policy through Line of Exchange and Exchange Rate. Thesis. Bogor Agricultural Institute.

Gujarati, Damodar, N and Porter, Dawn, C. (Mangunsong, Raden Carlos). (2012).
Fundamentals of Econometrics. Book 2, Issue 5. Jakarta: Publisher Salemba Empat.

Kadir, Abdul M, Priyo R. Widodo \& Guruh Suryani R. (2008). Implementation of Monetary Policy in the Framework of Inflation Targeting in Indonesia. Book Series for Central Bank No 21. Center for Education and Central Bank Studies (PPSK). Bank Indonesia.

Mgadmi, N., Chrigui, Z. 2015. Monetary policy's transmission channels in Tunisia: SVAR Model validation. Journal of Business and Management Research, 8, 189-200.

Natsir. M. (2009). Empirical Analysis Effectiveness of Monetary Policy Transmission Mechanism in Indonesia through Expectations of Inflation Rate Period 1990: 2-2007: 1. Faculty of Economics Unhalu University. Kendari.

Prasetyo, P. Eko. (2009). Macro Economics Fundamentals. Beta Offset Yogyakarta. Yogyakarta.

Simorangkir, Iskandar. (2014). Introduction to Central Bank: Theory and Practice in Indonesia. Central Bank's Research and Education Center. Bank Indonesia. PT Raja Grafindo Persada. Jakarta.

Simorangkir, Iskandar \& Suseno. (2004). Exchange Rate System and Policy. Central Bank Book Series No 12. Center for Education and Central Bank Studies. Bank Indonesia.

Suseno, \& Siti Astiya. (2009). Inflation. No. Central Bank Series 22. Center for Education and Central Bank Studies. Bank Indonesia

Act Number 23 of 1999 concerning Bank Indonesia

Act Number 3 of 2004 concerning Bank Indonesia

Act Number 6 of 2009 concerning Bank Indonesia

Warjiyo, Perry \& M Juhro Solikin. (2016). Central Bank Policy, Theory and Practice. PT. Raja Grafindo Persada. Jakarta.

(2003). Monetary Policy in Indonesia. Central Bank Book Series No.6. Center for Education and Study of Central Bank (PPSK) of Bank Indonesia.

Turguttopba, N. 2017. Perspectives on Monetary Policy and Cost of Capital: Evidence from Turkey. Journal of Central Banking Theory and Practice, 2, 45-64.

Uzoma, A. O., Bowale, E. E., Ogundipe, A. A. 2017. Monetary Policy Shocks and Manufacturing Sector Output in Nigeria: A Structural VarApproach. Journal of Internet Banking and Commerce 22(S8).

Warjiyo, Perry. (2004). Mechanism of Monetary Policy Transmission in Indonesia. Central 
Ilma Ulfatul \& Amin Pujiati/ Economics Development Analysis Journal 6 (4) (2017)

Bank Book Series No.11. Center for Education and Study of Central bank (PPSK) of Bank Indonesia.

Widarjono, Agus. (2009). Econometrics Introduction and Its Application. Penerbit Ekonesia. Yogyakarta. 